\title{
KOMUNIKATY
}

\author{
ELżBIETA HolEWIŃSKA-ŁAPIŃSKA
}

Uniwersytet Warszawski

\section{WYNIKI BADAŃ OPINII SĘDZIÓW \\ O PRZEDSTAWIONYM W „ZIELONEJ KSIĘDZE” \\ USYTUOWANIU PRAWA RODZINNEGO W PRZYSZŁEJ KODYFIKACJI}

I. W 2006 r. Ministerstwo Sprawiedliwości opublikowało dokument zatytułowany: Zielona Ksiega. Optymalna wizja Kodeksu cywilnego w Rzeczypospolitej Polskiej ${ }^{1}$. Przewiduje on włączenie do projektowanego kodeksu cywilnego prawa rodzinnego i opiekuńczego, jako księgi IV (po prawie zobowiązań a przed prawem spadkowym). Projekt całego kodeksu cywilnego ma zostać zrealizowany w 2010 r. $^{2}$

Stowarzyszenie Sędziów Rodzinnych w Polsce, przy pomocy organizacyjno-technicznej Instytutu Badań DNA - Wydawcy kwartalnika

${ }^{1}$ Dokument powstał dzięki udziałowi członków Komisji Kodyfikacyjnej oraz szerszego grona prawników, zarówno pracowników naukowych jak i praktyków, którzy pracowali w zespołach problemowych. Pomocy udzielili także eksperci holenderscy przekazując informacje ,o najnowszej w Europie Zachodniej kodyfikacji holenderskiej, innych kodyfikacjach zachodnioeuropejskich, a także o prawie cywilnym UE" (Por. Ministerstwo Sprawiedliwości. Komisja Kodyfikacyjna Prawa Cywilnego. Zielona Księga. Optymalna wizja Kodeksu cywilnego w Rzeczypospolitej Polskiej, red. Z. RADWAŃSKI, Warszawa 2006, s. 9).

${ }^{2}$ Z. Radwański, Prace nad kodyfikacja prawa cywilnego $w$ Polsce, «Rodzina i Prawo» 2007 nr 3 (6), s. 8. 
«Rodzina i Prawo», skierowało do sędziów anonimową ankietę zawierająca pytania o miejsce prawa rodzinnego w przyszłej kodyfikacji ${ }^{3}$. Niniejszy komunikat zawiera najważniejsze jej wyniki ${ }^{4}$.

W badaniu wzięło udział 956 sędziów, głównie z sądów rejonowych i okręgowych. Sędziowie, którzy zgodnie ze specjalizacją orzeczniczą mogą być uważani za sędziów rodzinnych (orzekający w wydziałach rodzinnych i nieletnich sądów rejonowych oraz w wydziałach/sekcjach rodzinnych sądów okręgowych), stanowili 55\% badanych (527 osób). Sędziów orzekających w wydziałach cywilnych było $411(43 \%)$. Pozostali ankietowani sędziowie (18 osób) orzekali w innych sądach.

Za kodeksową samodzielnością prawa rodzinnego, a więc przeciwko włączeniu przepisów z zakresu prawa rodzinnego do kodeksu cywilnego, opowiedziało się 671 sędziów, czyli $70 \%$ badanych. Za włączeniem przepisów z zakresu prawa rodzinnego do kodeksu cywilnego (jako jego księgi) było 157 osób ( $16 \%$ ankietowanych sędziów). 76 sędziów (8\%) nie zajęło jednoznacznego stanowiska wyrażając pogląd, iż równie doniosłe argumenty przemawiają za zachowaniem dotychczasowej kodeksowej odrębności prawa rodzinnego jak i za propozycją przedstawioną w „Zielonej Księdze”. Pozostali przyznali, że nie mają przemyślanego stanowiska na temat optymalnego usytuowania norm prawa rodzinnego.

Jeżeli uwzględni się tylko tych ankietowanych, którzy wyrazili zdecydowane stanowisko - za kodeksową samodzielnością prawa rodzinnego lub za włączeniem przepisów z tego zakresu do przyszłego kodeksu cywilnego - a więc 828 sędziów, to okazuje

${ }^{3} \mathrm{~W}$ ankiecie były przedstawione pytania dotyczące włączenia prawa rodzinnego do kodeksu cywilnego bądź kodeksowej odrębności prawa rodzinnego oraz pytania o uzasadnienie zajętego stanowiska (w postaci skategoryzowanej, uwzględniające argumenty najczęściej wypowiadane na uzasadnienie każdego ze stanowisk oraz dodatkowe pytania ,otwarte”, umożliwiające podanie innego lub dodatkowego argumentu na rzecz prezentowanego przez ankietowanego poglądu).

${ }^{4}$ Sprawozdanie z badania będzie opublikowane w kwartalniku «Rodzina i Prawo» (prawdopodobnie w nr 1 z 2008 r.). 
się, że za odrębnością kodeksową prawa rodzinnego opowiedziało się $81 \%$ spośród nich, zaś za koncepcją zaproponowaną w ,Zielonej Księdze” 19\%.

II. 1. Zwolennicy zachowania kodeksu rodzinnego obok kodeksu cywilnego (671 sędziów stanowi 100\% tej grupy badanych) najczęściej argumentowali swe stanowisko w wskazany niżej sposób.

- 461 sędziów (69\%) uważało, że prawo rodzinne jest już samodzielną gałęzią prawa. Dlatego jest oczywiste, że nie może być unormowane w kodeksie cywilnym.

- 374 badanych (56\%) wskazało, iż specyfika spraw rodzinnych wymaga głębokiej specjalizacji sędziów i uzasadnia rozwój sądownictwa rodzinnego, które powinno być, co najmniej, dwuinstancyjne (rejonowe i okręgowe sądy rodzinne). Odrębność kodeksowa prawa rodzinnego podkreśla specyfikę normowanych stosunków społecznych, dlatego przemawia za umocnieniem i rozwojem sądownictwa rodzinnego.

- 248 sędziów (37\%) było zdania, że samodzielność kodeksowa prawa rodzinnego ułatwia poznanie stanu prawnego i korzystanie z tej wiedzy przez nieprofesjonalistów, czyli przeważającą większość adresatów norm rodzinnoprawnych, którzy nie mają przygotowania prawniczego.

- 219 badanych (33\%) wskazało, iż tradycja przemawia za zachowaniem kodeksu rodzinnego, bowiem od 57 lat stosunki rodzinne są normowane przez poświęcony im kodeks.

- 203 ankietowanych (30\%) wskazało, iż nowy kodeks cywilny nie może być nadmiernie rozbudowany. Będzie to, bowiem bardzo utrudniało korzystanie z niego. Dlatego poszerzanie go o prawo rodzinne jest niecelowe.

2. Zwolennicy koncepcji prawa rodzinnego jako IV księgi projektowanego kodeksu cywilnego (157 sędziów stanowi $100 \%$ tej grupy badanych) na poparcie swego stanowiska powoływali niżej wskazane argumenty.

- 142 sędziów (90\%) było zdania, iż prawo rodzinne jest działem prawa cywilnego. 
- Przeświadczenie, iż nie jest możliwe stworzenie oddzielnej „pełnej” (zupełnej a nie „kadłubkowej”s) kodyfikacji prawa rodzinnego było udziałem 69 sędziów (44\%).

- W „Zielonej Księdze” został wypowiedziany pogląd, iż „Kodeks cywilny jest najdonioślejszym aktem normatywnym po Konstytucji"'. W konsekwencji, podzielający takie stanowisko traktują zamieszczenie przepisów w tym akcie normatywnym za „,dowartościowanie” problematyki, którą one normują. Tak też oceniło perspektywę zamieszczenia prawa rodzinnego w kodeksie cywilnym 30 sędziów.

- W państwach Europy Zachodniej, zgodnie z tradycją wielkich XIX wiecznych kodeksów cywilnych (które obowiązywały także na ziemiach polskich), prawo rodzinne należało do prawa cywilnego. Ten argument prawnoporównawczy podało 24 sędziów.

- W „Zielonej Księdze” został wypowiedziany pogląd, iż „pięćdziesięcioletnia tradycja uksztaltowana pod naciskiem doktryny komunistycznej nie powinna decydować o ksztatcie systemu prawnego $R P . "$. Stanowisko takie uznało za swoje 11 ankietowanych.

3. Należy zauważyć, że tylko dla części sędziów w sposób niewattpliwy o miejscu prawa rodzinnego w kodyfikacji przesądziło stanowisko merytoryczne odnośnie do miejsca tego prawa w systemie polskiego prawa.

- 461 sędziów na 956 badanych (48\%) uważało, że prawo rodzinne wyodrębniło się z prawa cywilnego i dlatego nie może być księgą kodeksu cywilnego.

- 142 sędziów (15\%) było zdania, że prawo rodzinne przynależy do prawa cywilnego.

Dla pozostałych inne argumenty były przesądzające przy wyborze stanowiska co do samodzielności kodeksowej prawa rodzinnego lub celowości jego unormowania w przyszłym kodeksie cywilnym.

${ }^{5}$ Zob. T. SMYczYŃski, Prawo rodzinne i stosunki rodzinnoprawne, «Studia z Prawa Prywatnego» 2007 z. 1(4), s. 18.

${ }^{6}$ Zielona Ksiega, cit., s. 32.

${ }^{7}$ Zielona Księga, cit., s. 31-32. 
4. Badanie wykazało, że specjalizacja orzecznicza ma wpływ na poglądy w omawianej kwestii. Sędziowie rodzinni (orzekający w sądach rejonowych i okreggowych) łącznie stanowili $64 \%$ wszystkich zwolenników tezy o celowości zachowania odrębności kodeksowej prawa rodzinnego. Sędziowie - cywiliści z sądów grodzkich, rejonowych i okręgowych stanowili około $35 \%$ aprobujących zdecydowanie wskazane stanowisko.

Zdecydowanie za odrębnością kodeksową prawa rodzinnego opowiedziało się 427 sędziów rodzinnych (81\% spośród wszystkich 527 sędziów rodzinnych, orzekających w sądach rejonowych i okregowych, którzy uczestniczyli w badaniu) oraz 232 sędziów - 56,4\% spośród 411 sędziów - cywilistów, orzekających w wydziałach cywilnych sądów grodzkich, rejonowych i okręgowych, którzy uczestniczyli w badaniu.

Należy podkreślić, że za kodeksową samodzielnością prawa rodzinnego opowiedziała się zarówno większość sędziów rodzinnych, jak i sędziów cywilnych. Jednakże pogląd ten był w sposób bezwzględny dominujący wśród sędziów rodzinnych.

5. Pewien wpływ na zajęte stanowisko miał wiek ankietowanych i staż orzeczniczy. W grupie najmłodszych sędziów, liczących nie więcej niż 35 lat, za kodeksową odrębnością prawa rodzinnego opowiedziało się $57 \%$ badanych, zaś wśród sędziów od 36 roku życia odsetek ten wynosił nie mniej niż 74 . Także wraz ze wzrostem długości stażu orzeczniczego zwiększał się odsetek zwolenników zachowania kodeksowej samodzielności prawa rodzinnego. Powyższe ustalenie zdaje się wspierać tezę, że im większe było doświadczenie życiowe i zawodowe ankietowanych, tym częściej rodziło się przeświadczenie, że właściwą koncepcją jest samodzielność kodeksowa prawa rodzinnego.

III. Wyniki badania powinny stać się przyczynkiem do dyskusji, bowiem dla większości pytanych sędziów, choć z różnych przyczyn, propozycja przedstawiona w „Zielonej Księdze” odnośnie do miejsca prawa rodzinnego w przyszłej kodyfikacji nie jest wizją optymalną. 
Wydaje się, iż szczególną wagę należy przywiązywać do stanowiska sędziów rodzinnych, którzy mają większą wiedzę teoretyczną i praktyczną w zakresie prawa rodzinnego nie tylko od pozostałych uczestników badania ale i od innych prawników, którym ta problematyka jest znana tylko teoretycznie. Mają też bezpośrednie spostrzeżenia na temat zarówno prawnej jak i społeczno - demograficznej problematyki rodzinnej. W tym zakresie można im więc przypisać przymioty eksperckie ${ }^{8}$. Należy też odnotować, że uchwała IX Kongresu Sędziów Sądów Rodzinnych w Polsce, który odbył się w dniach 2-4 października 2007 r. w Zakopanym, popiera koncepcję zachowania samodzielności kodeksowej prawa rodzinnego.

\section{Załacznik:}

\section{Uchwaza Stowarzyszenia Sędziów Sądów Rodzinnych w Polsce ZaKopane, dNia 4 PaŹdZiernika 2007 r.}

„Sędziowie zgromadzeni na IX Kongresie Stowarzyszenia Sędziów Sądów Rodzinnych w Polsce, w dniach od 2 do 4 października 2007 r. w Zakopanem, wyrażają podziękowanie Ministerstwu Sprawiedliwości za zrealizowanie naszych postulatów zgłaszanych od 1999 r. w sprawie ustawowego uregulowania awansu poziomego dla sędziów. Liczymy także na wsparcie w sprawie realizacji postulatu wprowadzenia podyplomowych studiów dwuletnich dla sędziów rodzinnych w zakresie uwzględniającym problematykę psychologiczną i pedagogiczną.

Ponadto, uczestnicy Kongresu uchwalają - co następuje: poprzeć uchwałę Krajowej Rady Sądownictwa w sprawie wystapienia do Prezydenta RP o zmianę rozporządzenia o wynagrodzeniach dla sędziów sądów powszechnych;

${ }^{8}$ Zob. M. ARCZEWSKA, Społeczne role sędziów rodzinnych-wyniki badań własnych, «Rodzina i Prawo» 2007 nr 3(6), s. 17-18. 
1) wyrazić sprzeciw wobec projektów włączenia wydziałów rodzinnych i nieletnich do wydziałów cywilnych;

2) wyrazić sprzeciw wobec projektów włączenia do kodeksu cywilnego przepisów kodeksu rodzinnego i opiekuńczego;

3) zgłosić propozycję ustawowego uregulowania postępowania wykonawczego $\mathrm{w}$ zakresie spraw opiekuńczych i nieletnich w miejsce dotychczasowych przepisów „Regulaminu wewnętrznego urzędowania sądów powszechnych";

4) wystapić ponownie o wprowadzenie jednolitego sądownictwa rodzinnego we wszystkich instancjach w sądach powszechnych;

5) podjąć działania wspierające powołanie specjalistycznych zakładów wychowawczo-leczniczych dla nieletnich zagrożonych różnego typu uzależnieniami i uzależnionych, oraz dla nieletnich z zaburzeniami osobowości;

6) poprzeć starania Stowarzyszenia Praw Ojców mające na celu zwiększenie udziału ojca w procesie wychowania dziecka oraz poprawę wykonalności orzeczeń regulujących kontakty rodzica z dzieckiem;

7) poprzeć starania środowiska akademickiego zmierzające do utworzenia katedr prawa rodzinnego i nieletnich;

8) podjąc starania zmierzające do przyznania Krajowej Radzie Sądownictwa prawa inicjatywy ustawodawczej;

Zobowiązać Zarząd Stowarzyszenia Sędziów Sądów Rodzinnych w Polsce do wykonania w całości postanowień powyższej uchwały. 